\title{
MIR128-1 Pre-miRNA
}

National Cancer Institute

\section{Source}

National Cancer Institute. MIR128-1 Pre-miRNA. NCI Thesaurus. Code C82761.

MIR128-1 is an oligoribonucleotide that is encoded by the human MIR128-1 gene and has a role in the regulation of gene expression. 